UDK $577.1: 61$

ISSN 1452-8258

J Med Biochem 38: 22-32, 2019

\title{
AGE AND ASSAY RELATED CHANGES OF LABORATORY THYROID FUNCTION TESTS IN THE REFERENCE FEMALE POPULATION
}

\author{
UTICAJ STAROSNE DOBI I ANALITIČKIH FAKTORA NA VRIJEDNOSTI PARAMETRA \\ ZA PROCJENU FUNKCIJE ŠTITNE ŽLIJEZDE U REFERENTNOJ POPULACIJI ŽENA
}

\author{
Najdana Gligorovic Barhanovic ${ }^{1}$, Tanja Antunovic ${ }^{1}$, Sreten Kavaric ${ }^{2}$, \\ Aleksandar Djogo ${ }^{2}$, Vesna Kalimanovska Spasojevic ${ }^{3}$ \\ ${ }^{1}$ Center for Clinical Laboratory Diagnostic, Clinical Center of Montenegro, Podgorica, Montenegro \\ ${ }^{2}$ Internal Disease Clinic, Department of Endocrinology, Clinical Center of Montenegro, Podgorica, Montenegro \\ ${ }^{3}$ Institute for Medical Biochemistry, Faculty of Pharmacy, University of Belgrade, Serbia
}

\section{Summary}

Background: Laboratory thyroid function tests play a central role in the diagnosis of thyroid disorders. The aim of our cross-sectional study was to determine reference values for thyroid tests in a rigorously selected group of Montenegrin females, investigate the impact of possible age-related changes and the influence of the interassay bias between three frequently used immunoassays.

Methods: Female subjects were randomly selected, aged between 20 and 69 and 946 of them met the selection criteria. TSH, fT3, fT4, thyroid peroxidase and thyroglobulin antibodies were measured. Eighty samples were further analyzed on two other immunochemistry platforms. Results: Median TSH progressively increased with age, there was no difference in fT3, while fT4 was significantly higher in the two oldest groups compared to the others. When using the age-related 97.5 percentile of TSH the percentage of reclassification was highest in the 20-29 years of age group $(5.2 \%, \mathrm{p}<0.05)$. In the oldest band, $7.7 \%$ had TSH values above cohort-specific and below the age-related upper reference limit. Bland-Altman bias plots revealed the highest interassay absolute mean difference between compared TSH assays of $24.5 \%$ and for fT4 assays of $13.8 \%$.

Conclusions: The correlation coefficients between fT3 assays from different manufacturers were low. Serum TSH and $\mathrm{fT} 4$ concentrations increased with age and the implementation of age-specific TSH reference intervals would be of interest. The bias between the three commercial

\section{Kratak sadržaj}

Uvod: Laboratorijski testovi za procjenu funkcije štitne žlijezde imaju centralno mjesto u dijagnostici poremećaja njene funkcije. Cilj našeg istraživanja bio je odrediti referentne vrijednosti za ove testove u rigorozno odabranoj grupi crnogorskih žena, istražiti uticaj starosne dobi, kao i interesej razlike između tri često korišćene imunohemijske platforme, na dobijene vrijednosti.

Metode: 946 ispitanica, slučajno odabranih u uzrastu između 20 i 69 godina, ispunile su kritrijume za izbor u referentnu populaciju. Mjereni su: TSH, fT3, fT4, tireoperoksidazna i tireoglobulinska antitijela. Osamdeset uzoraka dodatno je analizirano na dvije različite imunohemijske platforme.

Rezultati: Medijana TSH progresivno je rasla sa godinama, nije bilo razlike $u$ vrijednostima fT3, dok je fT4 bio znatno veći u dvije najstarije grupe u poređenju sa ostalim. Primjena 97,5 percentila vrijednosti TSH, karakterističnog za različite starosne grupe, uzrokovala je reklasifikaciju rezultata iz normalnih u patološke u svim grupama (najveći procenata u 20-29 godina grupi, 5,2\%, p <0,05), izuzev najstarije. $U$ najstarijoj grupi $7,7 \%$ ispitanica imalo je vrijednosti TSH iznad populacione, a u granicama za tu grupu dobijenih referentnih vrijednosti. Koncentracije serumskog TSH i fT4 rasle su sa godinama, te bi primjena referentnih vrijednosti specifičnih za datu starosnu grupu bila od značaja. Najveća apsolutna razlika srednjih vrijednosti između TSH testova bila je $24,5 \%$, a između fT4 testova $13,8 \%$.

Zaključak: Koeficijenti korelacije između fT3 testova različitih proizvođača bili su niski. Odstupanje između tri često

Address for correspondence:

Najdana Gligorovic Barhanovic,

Ljubljanska BB, 81000 Podgorica, Montenegro

najdana.gligorovic@kccg.me

List of abbreviations: $\mathrm{SCH}$, subclinical hypothyroidism; TFT, thyroid function tests 
immunoassays indicated that the standardization of thyroid function tests is a task of great importance.

Keywords: age, assays, reference values, thyroid function tests

\section{Introduction}

The signs and symptoms of thyroid diseases, especially subclinical hypothyroidism $(\mathrm{SCH})$, are neither sensitive nor specific, so diagnosis mainly depends on a laboratory thyroid function tests (TFT). Therefore, the distinction between a normal and an abnormal TFT result is critical in the recognition of thyroid disorders. The prevalence of thyroid dysfunction is 5-10 times higher in women compared to men, which might be explained by range of factors (1). In the female population, thyroid hormones play an important role in normal ovarian function (2), so reference limits for women in their reproductive period could be of help, especially in fertility challenged ones. (3) The measurement of the thyroid-stimulating hormone (TSH) is the most sensitive and widely used as a "first-step " screening test for primary thyroid disorders (4). The determination of its reference limits (especially the upper limit) is challenging for many different reasons and has been a subject of ongoing debate for the last fifteen years. Median population thyrotropin values are usually between $1-1.5 \mathrm{mU} / \mathrm{L}$ $(5,6)$ but they do not have a normal distribution, and rather display a right skewed one, with a long tail towards higher values. In 2005, Wartofsky and Dickey (7) advocated the lowering of the upper TSH limit from $4-5 \mathrm{mU} / \mathrm{L}$ to $2.5 \mathrm{mU} / \mathrm{L}$ since more than $95 \%$ of the normal population has a value below this limit. They suggested that persons with higher values are at risk of early thyroid failure. In contrast, some authors point out the huge medical and economical effect of the proposed change, leading to a nearly 4-fold increase in the prevalence of hypothyroidism $(8,9)$ and the adverse health effects of thyroxin treatment $(10,11)$.

The difficulties in the upper TSH limit determination are partly caused by differences in the TSH reference values established in some of the studies conducted so far (12-15). These discrepancies can be partially explained by different preanalytical and analytical factors. Preanalytical influences are related to subject selection criteria, the age of the participants (16) and the time period of the sample collection (17). The iodine status of the population is another possible factor affecting TFT reference values, especially thyrotropin ones (18) and it changes with ageing. The Balkan region has been an iodine deficient area, but in our country the process of salt iodization started in the 1950s, so that deficiency was eradicated and according to the results of the most recent study conducted in 2007 - intake was adequate (19). korišćena komercijalna imunohemijska određivanja ukazuje na važnost standardizacije testova za procjenu funkcije tireoidne žlijezde.

Ključne reči: godine, određivanja, referentne vrijednosti, tireoidni funkcionalni testovi

According to some data, in circumstances of iodine sufficiency, general population TSH values tend to be higher $(14,20)$ and increase with age $(14,20,21)$ in contrast to iodine deficient areas $(5,22-24)$. So, if population specific reference values are not used, this could lead to the incorrect classification of elderly patients regarding thyroid function, in terms of subclinical hypothyroidism in particular. The exact mechanisms of the TSH change with ageing have not yet been clarified.

The analytical factors contributing to the differences in reference values are related to the lack of standardization, differences in the matrix of the calibrators and the specificity of the antibodies in the assays used for the determination of TFT (http://www.acb.org.uk docs/tftguidelinefinal - last accessed 8 January 2018)). As a consequence, the bias between assays from different manufacturers is very noticeable but the Clinical Society's guidelines still do not take it into account.

The focus of our research was to determine accurate TSH, free thyroxin (fT4) and free triiodothyronine (fT3) reference values in the female population between the ages of 20 and 69 by implementing strict reference population selection criteria. Since some data suggest a change in thyrotropin levels with ageing, we aimed to determine the age-related change in this population in order to investigate its relevance and impact on the laboratory diagnosis of subclinical hypothyroidism, in terms of both underdiagnosis and over-diagnosis in different age groups. In addition, by evaluating the changes in TFT against age we aimed to contribute to research in to the possible mechanisms causing this alteration. In order to determine the impact of method related variability on TFT values, we compared results of three different, commonly used assays.

\section{Materials and Methods}

\section{Subjects}

The study population was randomly selected and evaluated among female subjects, aged between 20 and 69, who attended a clinical laboratory over two consecutive years to perform routine laboratory tests, as a part of their health checkup. All the subjects who voluntarily agreed to participate were selfreported as healthy and completed a questionnaire that included the participant's name, date of birth, medical history, their personal and family history of 
thyroid diseases and any current medications. The Ethics Committee of the Clinical Centre of Montenegro approved the study and all the subjects gave written informed consent.

According to the National Academy of Clinical Biochemistry (NACB) Guidelines for the Diagnosis and Monitoring of Thyroid Diseases (25) and similar recommendations issued by the Association of Clinical Biochemistry and Laboratory Medicine (ACB) and the British Thyroid Association (BTA) (http:// www.acb.org.uk docs/tftguidelinefinal.pdf (last accessed 8 January 2017)) in 2006 »reference ranges should be established using specimens collected between 0800h and 1800h and using 95\% confidence limits from log transformed data, the reference population should have no personal or family history of thyroid dysfunction, be on no medication known to alter TSH and have no thyroid antibodies detectable by a sensitive assay«. The exclusion criteria in our study were: a personal and/or family history of thyroid disease, positive thyroglobulin and/or thyroid peroxidase antibodies, taking medicine affecting thyroid function (oral contraceptives, estrogen, glucocorticoids, anti-epileptic drugs, amiodarone, and lithium), a diagnosis or a suspected case of polycystic ovarian syndrome (PCOS), a history of severe non-thyroid illness, pregnancy and breast feeding. Those subjects with serum values of $\mathrm{TSH}<0.1 \mathrm{mU} / \mathrm{L}$ or $\mathrm{TSH}>10.0$ $\mathrm{mU} / \mathrm{L}$ were not further analyzed as these results indicate a high probability of thyroid dysfunction (26).

The women included in the study were divided in to five age-related groups: $20-29,30-39,40-49$, $50-59$ and $60-69$ years of age.

\section{Laboratory measurements}

The blood samples were collected between 7:00 - 9:00 AM, after an overnight fast to avoid diurnal variation which has been found to have a significant and considerable impact on TSH values (15). After centrifugation at 3000 RPM for 10 minutes, the serum levels of TSH, fT4, fT3, thyroid peroxidase antibodies (TPOAb) and thyroglobulin antibodies $(\mathrm{TgAb})$ were measured on the same day using an immunochemiluminiscent assay on the Architect i2000 platform (Abbott Laboratories, Diagnostic Division, Abbott Park, IL, USA). The total (within-laboratory) precision for all controls was less than or equal to $6 \%$ for $\mathrm{TSH}, 7.2 \%$ for fT3, $5.5 \%$ for fT4, $5.5 \%$ for TPOAb and $3.7 \%$ for TgAb. The reference intervals provided by the manufacturer for TSH are 0.35-4.94 mU/L, 9.5-19.0 pmol/L for fT4and 2.5$5.7 \mathrm{pmol} / \mathrm{L}$ for fT3. According to the package, inserts values of TPOAb lower than $5.6 \mathrm{IU} / \mathrm{mL}$ and $\mathrm{TgAb}$ below $4.1 \mathrm{mU} / \mathrm{L}$ are considered antibody negative.

Our subset of 80 samples were further analyzed on a Cobas e411 (Roche Diagnostic, GmbH, Penzberg, Germany) and an Immulite 2000XPI (Siemens
Healthcare $\mathrm{GmBH}$, Erlangen, Germany). TSH, fT3 and $\mathrm{fT} 4$ were measured, within-run imprecision determined for all the assays.

\section{Statistical analysis}

The Kolmogorov-Smirnov method was used to test for the normality of the TFT distributions. Since the TSH, $\log T S H$, fT3 and fT4 values were not normally distributed in the tested population all the results of the descriptive statistics are presented by nonparametric values. The Mann-Whitney test and Kruskal-Wallis test were used to compare the TFT values in different subpopulations. The range between the $2.5^{\text {th }}$ and the $97.5^{\text {th }}$ percentile was used to determine the reference intervals. Assays from different manufacturers were compared using the line of best fit by last square linear regression and Bland-Altman agreement method. Pearson chi test for categorical variables was used. A $p$ value $<0.05$ was considered statistically significant. The statistical analyses were performed using an SPSS version 20.0.

\section{Results}

A total of 946 subjects met the selection criteria before the measurement of the level of thyroid antibodies. One hundred and fifty-six subjects (16.5\%) with positive TPOAb and/or TgAb were further excluded from the reference population (Figure 1). The overall TSH $2.5^{\text {th }}$ and $97.5^{\text {th }}$ percentiles were $0.44 \mathrm{mU} / \mathrm{L}$ and $4.13 \mathrm{mU} / \mathrm{L}$. The reference range for fT3 was 3.3-5.8 pmol/L, and for fT4 it was 10.7$18.0 \mathrm{pmol} / \mathrm{L}$. The median, inter quartile range and the $2.5^{\text {th }}$ and $97.5^{\text {th }}$ percentiles of TFT for the five age-related groups are summarized in Table $I$.

Median TSH progressively increased with age, with the first significant increase in the 50-59 years

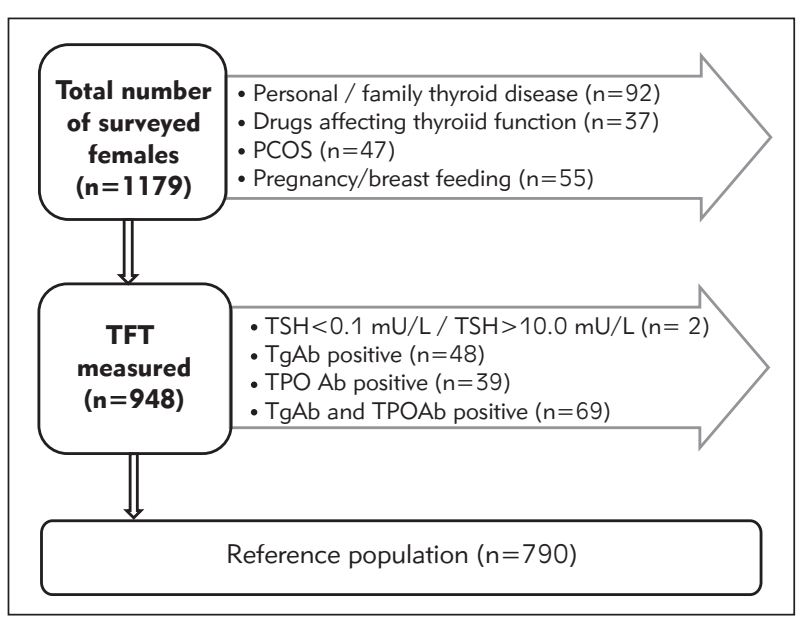

Figure 1 Flow-chart showing selection criteria of female subjects. 
Table I TSH, fT3 and fT4 concentrations in different age-related groups.

\begin{tabular}{|c|c|c|c|c|c|c|c|c|c|c|}
\hline Age group & & \multicolumn{3}{|c|}{$\mathrm{TSH}(\mathrm{mU} / \mathrm{L})$} & \multicolumn{3}{|c|}{ fT3 (pmol/L) } & \multicolumn{3}{|c|}{ fT4 (pmol/L) } \\
\hline (years) & $\mathrm{N}$ & $\begin{array}{c}\text { Median } \\
\left(I Q R^{*}\right)\end{array}$ & $\begin{array}{c}2.5^{\text {th }} \\
\text { percentile }\end{array}$ & $\begin{array}{c}97.5^{\text {th }} \\
\text { percentile }\end{array}$ & $\begin{array}{c}\text { Median } \\
\left(I Q R^{*}\right)\end{array}$ & $\begin{array}{c}2.5^{\text {th }} \\
\text { percentile }\end{array}$ & $\begin{array}{c}97.5^{\text {th }} \\
\text { percentile }\end{array}$ & $\begin{array}{c}\text { Median } \\
\left(I Q R^{*}\right)\end{array}$ & $\begin{array}{c}2.5^{\text {th }} \\
\text { percentile }\end{array}$ & $\begin{array}{c}97.5^{\text {th }} \\
\text { percentile }\end{array}$ \\
\hline $20-29$ & 172 & $\begin{array}{c}1.36 \\
(0.99)\end{array}$ & 0.31 & 3.21 & $4.6(0.9)$ & 3.30 & 5.80 & $13.1(2.0)$ & 10.70 & 17.53 \\
\hline $30-39$ & 198 & $\begin{array}{c}1.37 \\
(1.21)\end{array}$ & 0.37 & 3.60 & $4.6(0.9)$ & 3.20 & 5.70 & $13.1(1.6)$ & 10.59 & 16.11 \\
\hline $40-49$ & 157 & $\begin{array}{c}1.44 \\
(1.24)\end{array}$ & 0.42 & 4.20 & $4.5(0.9)$ & 3.30 & 6.30 & $13.2(2.1)$ & 10.40 & 18.10 \\
\hline $50-59$ & 133 & $\begin{array}{c}1.54 \\
(1.10)\end{array}$ & 0.56 & 4.43 & $4.7(0.8)$ & 3.30 & 5.80 & $14.0(2.32)$ & 10.70 & 18.14 \\
\hline $60-69$ & 130 & $\begin{array}{c}2.04 \\
(1.34)\end{array}$ & 0.69 & 5.07 & $4.6(0.7)$ & 3.20 & 6.50 & $14.7(3.0)$ & 11.01 & 19.08 \\
\hline
\end{tabular}

* - interquartile range

Table II Age specific distributions of TSH values in the selected population.

\begin{tabular}{|c|c|c|c|c|c|c|}
\hline \multirow{2}{*}{ Age group (years) } & \multirow{2}{*}{ Sample } & \multirow{2}{*}{ Total } & \multicolumn{4}{|c|}{ Percent in TSH category (mU/L) } \\
\hline & & & $<0.4$ & $0.4-2.49$ & $2.5-4.0$ & $>4.0$ \\
\hline Total & 790 & 100 & 1.7 & 77.2 & 17.3 & 3.8 \\
\hline 20-29 & 172 & 21.8 & 2.1 & 85.6 & 11.3 & 1.0 \\
\hline $30-39$ & 198 & 25.1 & 2.0 & 82.3 & 13.6 & 2.1 \\
\hline $40-49$ & 157 & 19.9 & 1.3 & 79.8 & 15.7 & 3.2 \\
\hline $50-59$ & 133 & 16.8 & 1.9 & 75.2 & 17.6 & 5.3 \\
\hline $60-69$ & 130 & 16.4 & 0.8 & 65.4 & 27.6 & 6.2 \\
\hline
\end{tabular}

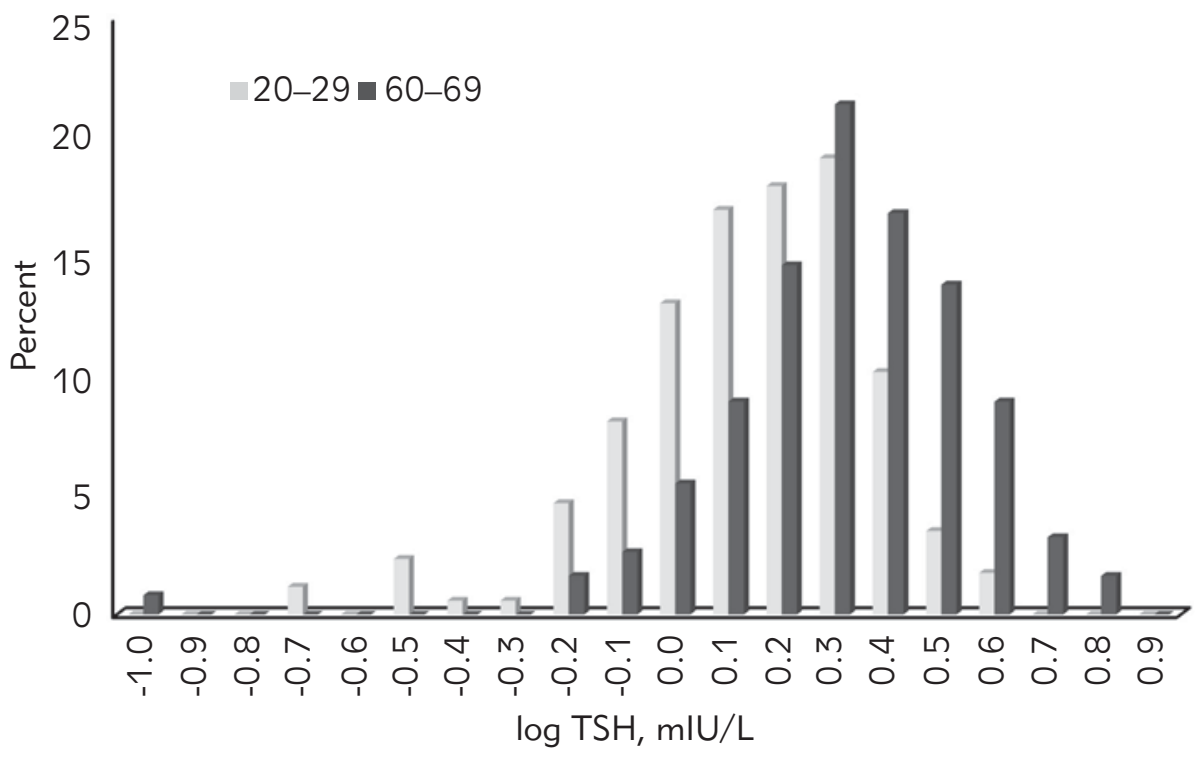

Figure $2 \mathrm{TSH}$ distribution in the youngest and oldest group. 
of age group. The median TSH value, being 2.04 $\mathrm{mU} / \mathrm{L}$, was significantly higher in the oldest group compared to all the other groups $(p<0.01)$. No statistically significant differences in the serum values of free triiodothyronine were observed between any of the groups $(p=0.17)$. Free thyroxin values were significantly higher in the two oldest groups compared to first, second and third age-related group $(p<0.01)$.

In order to determine the diagnostic relevance of these population specific and age-related TSH upper reference limits, the percentages of females categorized differently compared to the value proposed by manufacturer $(4.94 \mathrm{mU} / \mathrm{L})$ were calculated. When using the age-related 97.5 percentile, the percentage of reclassification from normal to abnormal was highest in the 20-29 years of age group (5.2\%, $\mathrm{p}<0.05)$, and in the age band 30-39 it was a still statistically significant $3.3 \%(p<0.05)$, while it was $2.2 \%$ and $2.5 \%$ in the groups at $40-49$ and $50-59$ years of age. In all these groups the age-specific upper reference interval was lower compared to that proposed by the manufacturer. In the oldest band, $1.1 \%$ of females had TSH values above $4.94 \mathrm{mU} / \mathrm{L}$ and $7.7 \%$ had TSH values above $4.13 \mathrm{mU} / \mathrm{L}$ and below the age-specific upper reference limit calculated for that group.

We analyzed the age-specific distribution of serum thyrotropin concentrations in the population (Table II) by categorizing the values in four groups: lower than 0.40 (Group 1), 0.40-2.49 (Group 2), 2.50-4.00 (Group 3) and greater than $4.00 \mathrm{mU} / \mathrm{L}$ (Group 4). The TSH values progressively shifted toward higher concentrations with aging. The percentage of values in different TSH groups was significantly different among woman in the five age-related bands. The frequency of the value categorized in Group 2 continuously decreased with age, while the percentage of TSH values in the range 2.50-4.00 $\mathrm{mU} / \mathrm{L}$ and greater than $4.00 \mathrm{mU} / \mathrm{L}$ continuously rose with age and was highest in the oldest group. The data suggest that the increase in the median, upper and lower reference limits, is potentially a consequence of changes in the distribution of TSH with age (Figure 2).

In order to evaluate the influence of the different assays on the TFT reference values, a comparison

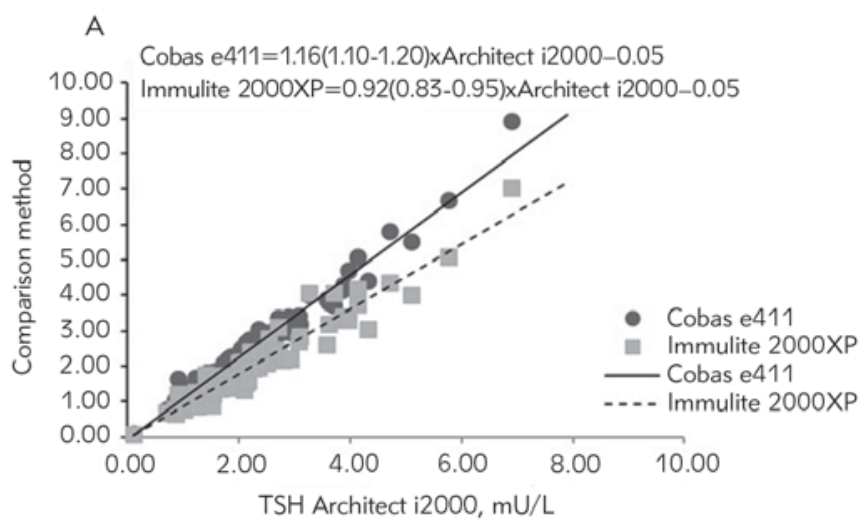

B

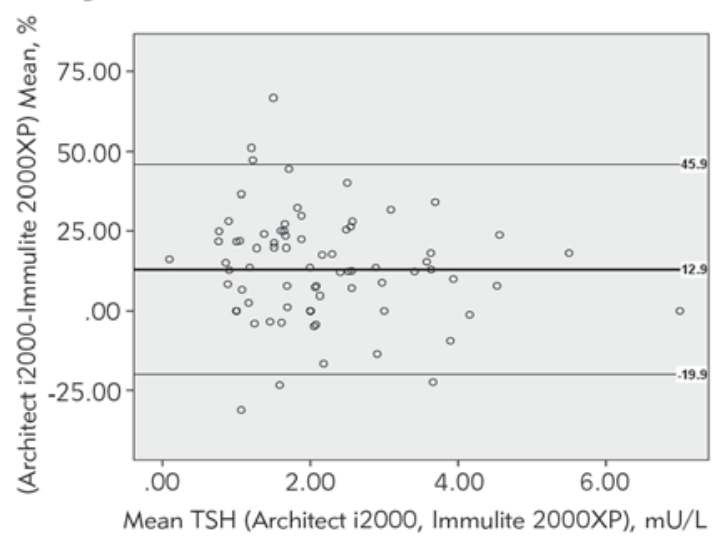

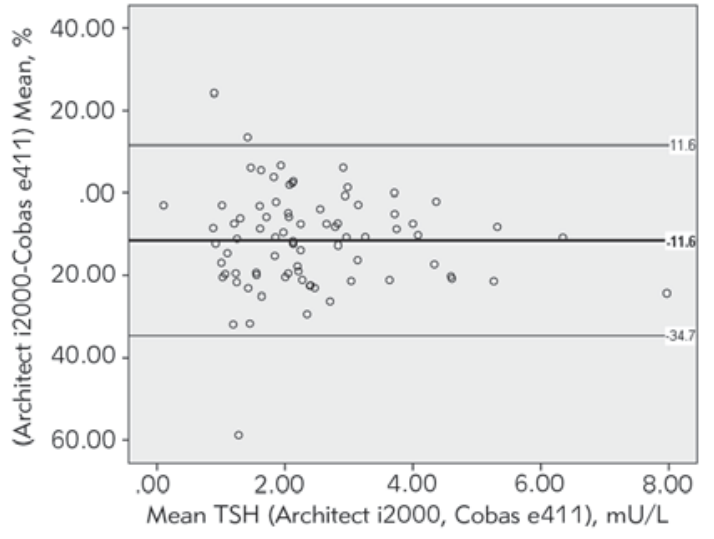

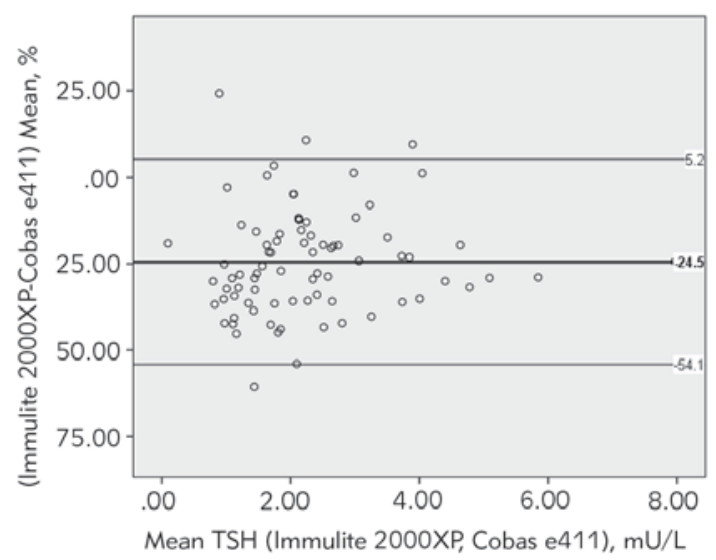

Figure 3 Comparison of TSH assays: (A) Regression lines (95\% confidence interval) and (B) Bland-Altman plots with mean \pm $1.96 \mathrm{SD}$ limits of agreement. 


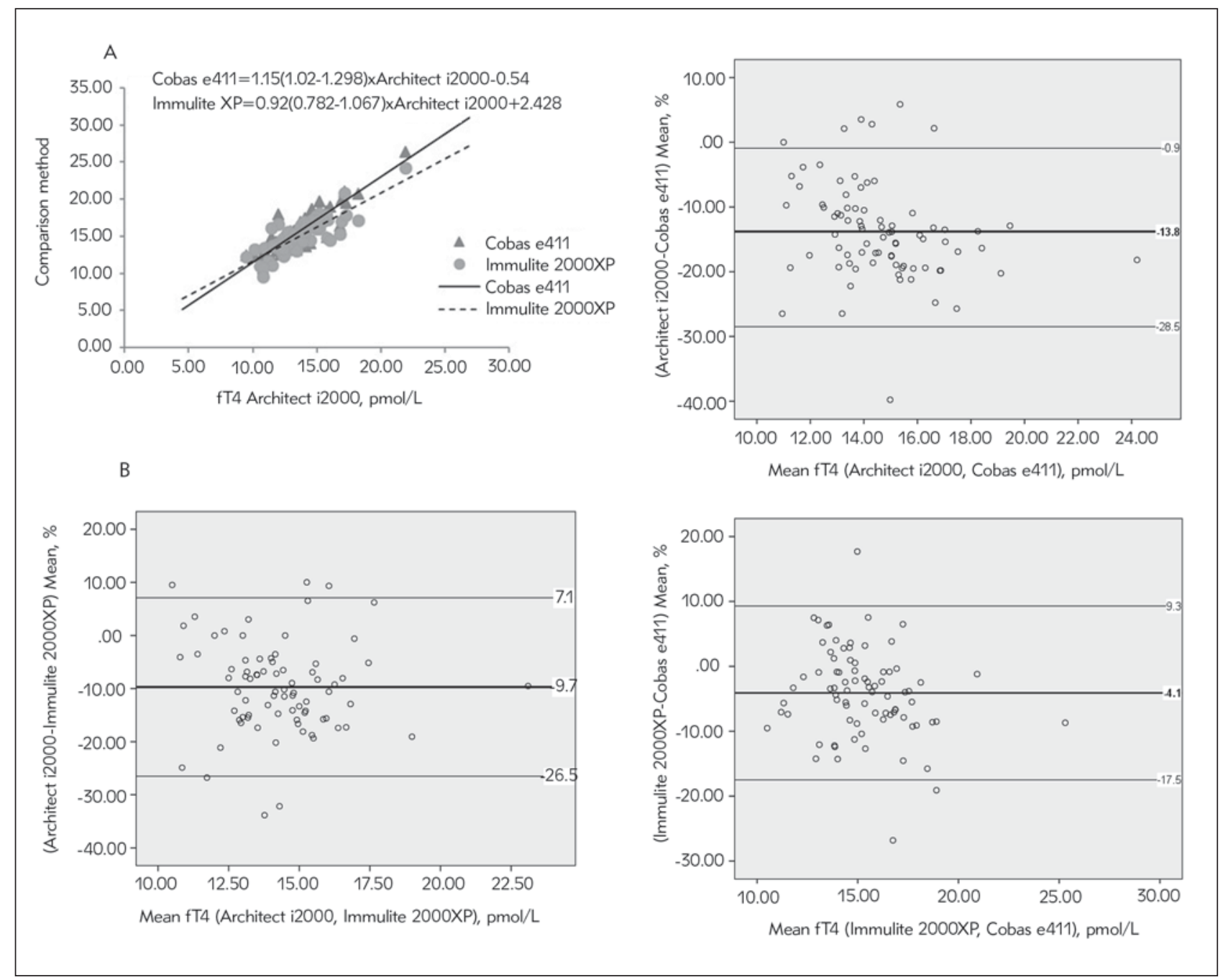

Figure 4 Comparison of fT4 assays: (A) Regression lines (95\% confidence intervals) and (B) Bland-Altman plots with mean \pm 1.96 SD limits of agreement.

study analyzing 80 samples using three TSH, fT4 and fT3 tests produced by different manufacturers was performed. All the samples were analyzed on the same day on each platform. For the regression analysis the thyroid hormone results from the Architect i2000 were used as a reference point and compared to the other assays (see Figure 3, 4 and 5). The assay precision for all the tests was determined by analyzing forty samples in duplicate on each analyzer. For TSH values of $0.5-5.0 \mathrm{mU} / \mathrm{L}$, the $\mathrm{CVs}$ were: $1.6 \%$ for the Architect i2000, 4.1\% for the Immulite 2000XP and $2.2 \%$ for the Cobas e411 assay. In terms of the fT4 assay, the CVs for a range of values from $10 \mathrm{pmol} / \mathrm{L}$ to $20 \mathrm{pmol} / \mathrm{L}$ : were $2.2 \%$ (on the Architect i2000), $2.7 \%$ (on the Immulite 2000XP) and 2.1\% (on the Cobas e411). The CVs for the fT3 values of 3.0-6.5 $\mathrm{pmol} / \mathrm{L}$ were similar $(2.5 \%$ on the Architect $\mathrm{i} 2000$ and $2.7 \%$ on the Cobas e411) except for those given by the Immulite 2000XP, on which the value was higher (5.9\%).
The regression analyses for the TSH values in the subset of 80 samples revealed the slope of 1.16 from the Cobas e411 and 0.92 from the Immulite 2000XP compared to the Architect i2000 results (Figure 3A). The Bland-Altman plots representing the relationship between the difference and the mean of three TSH assays are shown in Figure 3B. A positive bias of $12.9 \%$ was observed for TSH results measured with the Architect i2000 compared to Immulite 2000XP which yielded higher results on the first platform. By contrast, bias between Architect i2000/Cobas e411 and Immulite 2000XP/Cobas e411 was negative $(-11.6 \%$ and $-24.5 \%$, respectively). It is important to note that the manufacturer-proposed upper reference limits for the Immulite 2000XP and the Cobas e411 are the same $(4.20 \mathrm{mU} / \mathrm{L})$ despite the difference obtained.

In terms of the fT4 assays, the slope values were very similar to those for the TSH, 1.15 for the Cobas 


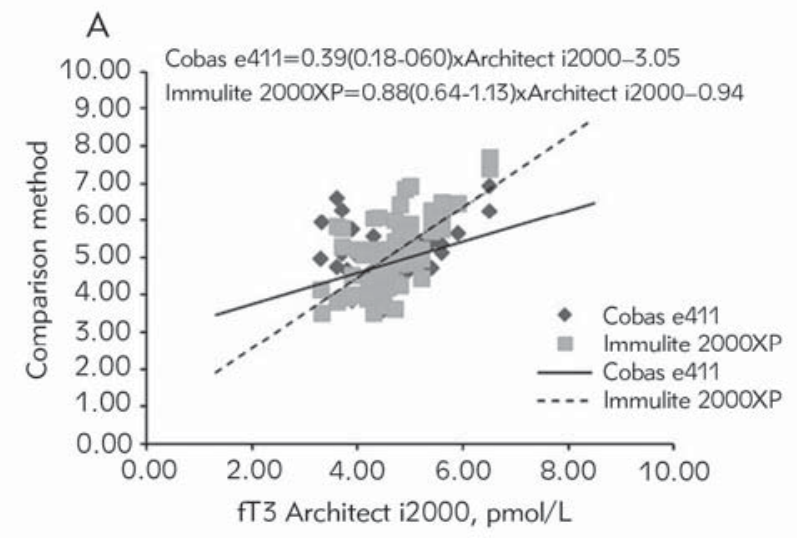

B

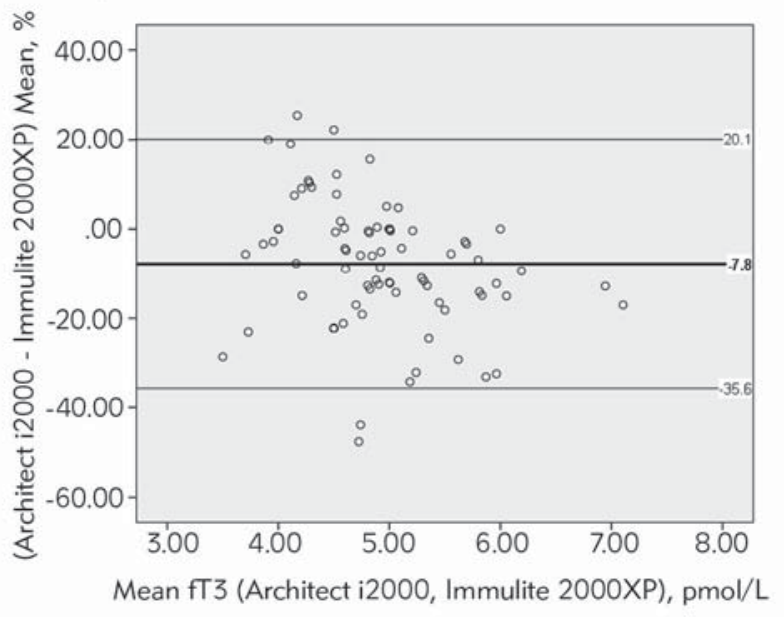

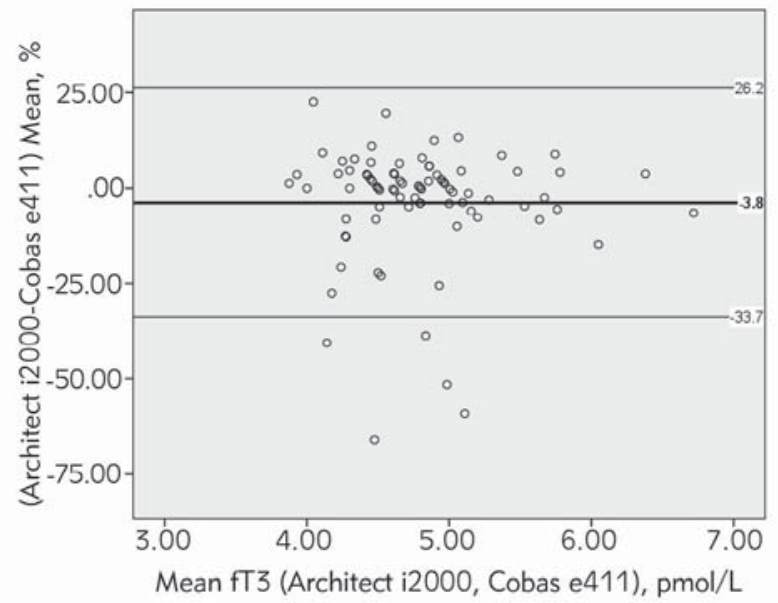

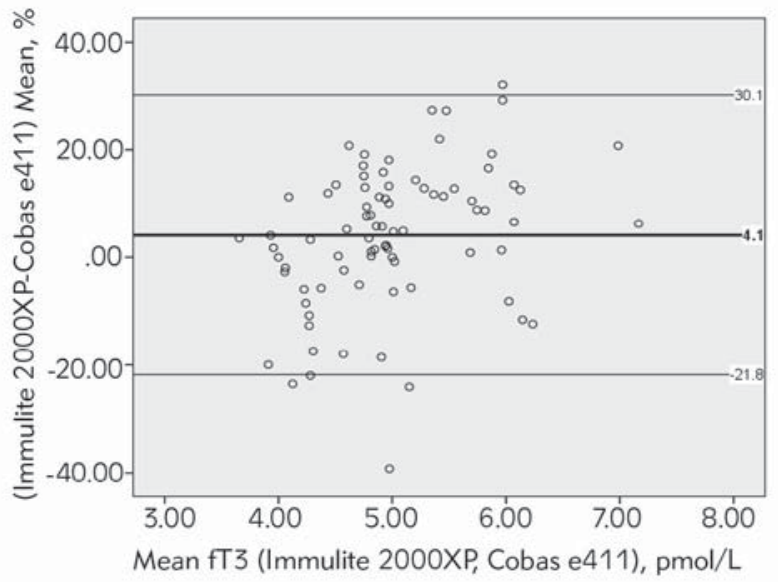

Figure 5 Comparison of fT3 assays: (A) Regression lines (95\% confidence intervals) and (B) Bland-Altman plots with mean \pm 1.96 SD limits of agreement.

e411 and 0.92 for the Immulite 2000XP, when compared to the Architect i2000 analyzer (Figure 4A). The Bland-Altman agreement method for fT4 assays showed the highest mean difference between Architect i2000 and Immulite 2000XP of 13.8\% (Figure 4B).

The correlation coefficients between fT3 concentrations in the same samples on different analyzers were low, with Abbott versus Roche giving 0.38 and Abbott versus Siemens producing 0.64, respectively (Figure 5A). Mean differences between three fT3 assays were $-7.8 \%, 3.8 \%$ and $4.1 \%$ (Figure $5 B$ ).

\section{Discussion}

To the best of our knowledge this is the first study designed to establish the age-related changes in the reference intervals of thyroid function tests in the South European - Balkan region which takes a population-based approach.
The overall reference range for TSH at 0.44 $\mathrm{mU} / \mathrm{L}-4.13 \mathrm{mU} / \mathrm{L}$ was similar to one proposed in the 2012 American Association of Clinical Endocrinologists (AACE) and American Thyroid Association (ATA) guidelines for a third generation TSH assay in iodine sufficient areas $(0.45 \mathrm{mU} / \mathrm{L}-4.12$ $\mathrm{mU} / \mathrm{L}$ ) (18). The upper limit was very similar to the one reported in a study conducted in another part of the Balkan region $(4.20 \mathrm{mU} / \mathrm{L})$ based on the indirect estimate of reference limits (12), but the values for different age bands were not in agreement. The calculated upper reference interval in our study was higher with regard to the data obtained from iodine deficient areas $(14,15)$. In two studies performed in Northern Germany, at an interval of ten years, during which iodine fortification was introduced, the upper TSH reference interval shifted towards the right and the upper limit (with no significant gender differences) raised from $2.12 \mathrm{mU} / \mathrm{L}(14)$ to $3.29 \mathrm{mU} / \mathrm{L}$ (15). Taken together, this results are in accordance with the recent AACE and ATA guidelines (18) under- 
lining the influence of current iodine status on the thyrotropin range.

Our reference interval for fT4 was narrower compared to that proposed by the manufacturer and in agreement with the results of the cross-sectional study (10.5-18.9 pmol/L) performed using the same method (12). The calculated fT3 $2.5^{\text {th }}$ percentile was higher and $97.5^{\text {th }}$ percentile similar to those that were proposed. In a study performed in Spain (27), using the same method, the lower fT3 reference limit (2.27-5.18 pmol/L) was more similar to that suggested by the manufacturers, but the age selection criteria were different and the number of subjects considerably lower when compared to our study.

Different data suggest that the change in thyrotropin levels with age varies depending on the iodine status of the population. The results of our investigation are consistent with some other previously conducted large population studies in areas with adequate iodine supplementation $(6,22,24)$, showing that the median, lower and upper reference limits of the serum thyrotropin values of female subjects continuously increased with age. Data from NHANES III show an increase in the hormone values with age in subjects with no biochemical or clinical signs of thyroid disease (28). The longitudinally designed study of Bremner et al, with 1212 of participants tested twice across an interval of thirteen years, has shown the association between ageing and an increase in $\mathrm{TSH}$ values (being significantly greater in the older population) without a significant change in fT4 concentrations (24). By contrast, some cross-sectional studies in populations with a mild or moderate iodine deficiency, in the absence of thyroid disease, have demonstrated a decrease in thyrotropin concentrations with aging $(14,20,21)$. Based on this data, the iodine supplementation of the investigated population was adequate.

As previously mentioned, in a study performed in another part of the Balkan region (12) based on the indirect estimate of TFT reference ranges, the 97.5 percentile of the TSH values in the youngest subjects (3.82 $\mathrm{mU} / \mathrm{L})$ was higher compared to ours $(3.21 \mathrm{mU} / \mathrm{L})$. The probable causes of this are related to the different approach used in subject selection and the inclusion of subjects younger than 20 years old in the Serbian study. In our study the question related to the subject's medical history included a sub-question on a diagnosis or suspected case of PCOS (which usually becomes apparent in the teens or early 20s) which is associated with a high prevalence of thyroid and autoimmune thyroid conditions (29), so it is possible that the inclusion of a greater number of patients with this condition affected the upper thyrotropin reference level in the youngest group in the Serbian study.

By contrast to a study performed in Western Australia (30), we had a significantly high percentage of females in the two youngest groups classified differently when the calculated age-specific upper TSH reference limits were applied. This is probably a consequence of the different thyrotropin values used for comparison. We evaluated the manufacturer proposed upper limit (4.94 $\mathrm{mU} / \mathrm{L})$ while in the investigation of Kahapola-Arachchige et al the results were compared with a much lower "common« cut-off of $4.0 \mathrm{mU} / \mathrm{L}$. The differences in subject selection criteria could further contribute to this discordance.

Although the definition of subclinical hypothyroidism $(\mathrm{SCH})$ is still controversial, in the female population of reproductive age (20-40 years old) there is sufficient data connecting it with fertility $(2,3,31$, 32). Our findings suggesting that the upper TSH reference level for the general population is slightly too high and that the use of an age-related upper limit for this population would be of interest.

In our oldest group, a significant percentage of patients would have been misclassified as hypothyroid if the upper TSH limit specific to that age group had not been applied. The results of various different studies $(5,23,33)$ are consistent with our data, demonstrating that higher concentrations of TSH in older patients are not always an indication of the need for thyroxin treatment.

We did not find any age-related change in fT3 values. In a study conducted in southern Italy a reduction in fT3 in advanced age subjects as a result of metabolic adjustments to a lower level of oxygen consumption, was found (34), but since our population was comprised of females who were younger than 70 years of age it is possible that this decline was not yet noticeable.

The current data on fT4 changes with age are conflicting. In our subjects, fT4 increased with age, with values significantly higher in the two oldest cohorts compared to the younger groups. The longitudinal study in an iodine sufficient area by Bremner et al. (24) showed that an increase in TSH was not followed by a decrease or even a small increase in FT4 levels with age in the elderly. A Cardiovascular Health Study in a very elderly subgroup found that a serum TSH increase by $13 \%$ over 13 years of followup was associated with a $1.7 \%$ increase in FT4 (35). In a historically iodine-deficient region in the Netherlands, FT4 levels were negatively associated with age in subjects aged 35-60 and positively associated in the elderly, aged 60 or older (36).

TSH values distribution analysis showed that the peak frequencies shifted towards higher concentrations with age (Figure 2). If the increase in the upper reference limit was a result of an increased prevalence of hypothyroidism, they would occur at the same TSH values in all groups. Therefore, the alteration of values with age, at least to some degree, represent an age-specific change in thyrotropin towards 
higher values, as has been found in some other studies $(6,22)$. The absence of a fall in the serum fT 4 values further contributes to the evidences that the agerelated rise in $\mathrm{TSH}$, in populations with adequate iodine intake, is not a consequence of occult thyroid diseases, but rather of an alteration in the TSH secretion set point. If the impaired TSH bioactivity or reduced responsiveness of the thyroid gland to the hormone with age were causing higher circulating TSH values, then thyroxine concentration would not be significantly different. But the type of change in fT4 values observed in our study suggests that increased TSH secretion could be a result of the impaired sensitivity of TSH-producing cells to thyroid hormones by the down-regulation of type 2 iodothyronine deiodinase activity in the pituitary (37). More studies are needed to clarify the exact causes of this TSH increase with age.

For every evaluated thyrotropin assay the precision was acceptable and calibrators traceable to the WHO Second International Reference Preparation $80 / 558$, but a bias between assays was evident. Immulite i2000 and Cobas e411 had proportional biases (with slope values of 1.16 and 0.92 , respectively) compared to Architect i2000 TSH values and the Bland-Altman method showed the mean absolute difference between three methods of $11.6 \%, 12.9 \%$ and $24.5 \%$. Those differences suggest that clinical guidelines should take in to account the bias between various commercial assays when "cut-off «TSH values are proposed. The proposed harmonization of thyrotropin assays may lead to the better agreement of results in the future (38).

The possible standardization of fT4 assays, according to an international conventional reference procedure, would change results significantly - perhaps by as much as $80 \%$ at the upper limit of the normal range - for some assays (39). The three assays compared in our study did not exhibit such a significant difference. Even the extreme absolute difference between assays described by the $95 \%$ limits of agreement did not exceed 36\%. The highest fT4 between method bias of $13.8 \%$ could have an impact on the diagnosis of thyroid dysfunction, particularly if the TSH values are between the upper limit of a reference range and $10 \mathrm{mU} / \mathrm{L}$.
The regression analyses revealed notable interassay variability in fT3 measurements in our study. Despite smaller mean differences, the Bland-Altman plots pointed out absolute extreme difference described by $95 \%$ limits of agreement exceeding 59\% between the methods. Since standardization is not expected in the near future, the recommendation to measure this hormone with the same assay for followup should probably remain in place.

\section{Conclusion}

In conclusion, in this selected reference female population, the serum TSH and fT4 concentrations increased with age due to modifications to the TSH set-point. The implementation of age-specific TSH reference intervals would be of interest especially for the youngest and the oldest cohort. Our results suggest the adequate iodine supplementation of the population. The impact of different TFT assays on reported values is significant (being similar to effects of age, except for fT3) and the standardization and/or harmonization of TFT remains a task of great importance. Until the realization of that goal, all measured TFT results should be evaluated in relation to population and assay specific decision limits.

\section{Funding}

This research did not receive any specific grant from any funding agency in the public, commercial or not-for-profit sector.

\section{Conflict of interest statement}

The authors declare that there is no conflict of interest that could be perceived as prejudicing the impartiality of the research reported. 


\section{References}

1. Prummel MF, Strieder T, Wiersinga WM. The environment and autoimmune thyroid diseases. Eur J Endocrinol 2004; 150: 605-18.

2. Evers AS. Paracrine Interactions of Thyroid Hormones and Thyroid Stimulation Hormone in the Female Reproductive Tract have an Impact on Female Fertility. Front Endocrinol (Lausanne). 2012; 3: 50.

3. Verma I, Sood R, Juneja S, Kaur S. Prevalence of hypothyroidism in infertile women and evaluation of response of treatment for hypothyroidism on infertility. Int J Appl Basic Med Res 2012; 2(1): 17-19.

4. Biondi B. The normal TSH reference range: what has changed in the last decade? J Clin Endocrinol Metab 2013; 98 (9): 3584-7.

5. Vadiveloo T, Donnan PT, Murphy MJ, Leese GP. Age- and gender-specific TSH reference intervals in people with no obvious thyroid disease in Tayside, Scotland: The thyroid Epidemiology, audit, and research Study (TEARS). J Clin Endocrinol Metab 2013; 98(3): 1147-53.

6. Mirjanic-Azaric B, Avram S, Stojakovic-Jelisavac T, Stojanovic D, Petkovic M, Bogavac-Stanojevic N, Ignjatovic $S$, Stojanov M. Direct estimation of reference intervals for thyroid parameters in the Republic of Srpska. J Med Biochem 2017; 36: 137-44.

7. Wartofsky L, Dickey RA. The evidence for a narrower thyrotropin reference range is compelling. J Clin Endocrinol Metab 2005; 90(9): 5483-8.

8. Pandrc SM, Ristić A, Kostovski V, Stanković M, Antić V, Milin-Lazović J, Ćirić J. The effect of early substitution of subclinical hypothyroidism on biochemical blood parameters and the quality of life. J Med Biochem 2017; 36: 127-36.

9. Surks MI, Goswami G, Daniels GH. Controversy in clinical endocrinology: the thyrotropin reference range should remain unchanged. J Clin Endocrinol Metab 2005; 90: 5489-549.

10. Gharib H, Tuttle RM, Baskin HJ, Fish LH, Singer PA, McDermott MT. Consensus statement \#1: subclinical thyroid dysfunction: a joint statement on management from the American Association of Clinical Endocrinologists, the American Thyroid Association, and The Endocrine Society. Thyroid 2005; 15: 24-8.

11. Biondi $B$, Cooper DS. The clinical significance of subclinical thyroid dysfunction. Endocrine Reviews 2008; 29: 76-13.

12. Milinković N, Ignjatović S, Žarković $M$, Jovičić S, Radosavljević B, Singh S, Majkić-Singh N. Indirect estimation of age-related reference limits of thyroid parameters: $A$ cross-sectional study of outpatients' results. Scand J Clin Lab Invest 2014: 74(5): 378-84.

13. Schalin-Jäntti $C$, Tanner $P$, Välimäki JM, Hämäläinen $E$. Serum TSH reference interval in healthy Finnish adults using the Abbott Architect 2000i Analyzer. Scand J Clin Lab Invest 2011; 71(4): 344-9.

14. Volzke H, Alte D, Kohlmann T, Ludemann J, Nauck M, John $U$, Meng W. Reference intervals of serum thyroid function tests in a previously iodine-deficient area. Thyroid 2005; 15: 279-85.
15. Ittermann T, Khattak RM, Nauck M, Cordova CMM, Völzke $\mathrm{H}$. Shift of the TSH reference range with improved iodine supply in Northeast Germany. Eur J Endocrinol 2015; 172(3): 261-7.

16. Laurberg $P$, Andersen S, Carle A, Karmisholt J, Knudsen $\mathrm{N}$, Pedersen IB. The TSH upper reference limit: where are we at? Nat Rev Endocrinol 2011; 7: 232-9.

17. Andersen IB, Brasen CL, Christensen H, Noehr-Jensen L, Nielsen DE, Brandslund I, Madsen JS. Standardised Resting Time Prior to Blood Sampling and Diurnal Variation Associated with Risk of Patient Misclassification: Results from Selected Biochemical Components. PLoS ONE 2015; 10(10): e0140475.

18. Garber JR, Cobin RH, Gharib H, Hennessey JV, Klein I, Mechanick JI, Pessah-Pollack R, Singer PA, Woeber KA. Clinical practice guidelines for hypothyroidism in adults: cosponsored by the American Association of Clinical Endocrinologists and the American Thyroid Association. Thyroid 2012; 22: 1200-35.

19. Van der Haar F, Gerasimov G, Tyler VQ, Timmer A. Universal salt iodization in the Central and Eastern Europe, Commonwealth of Independent States (CEE/CIS) Region during the decade 2000-2009: experiences, achievements, and lessons learned. Food and Nutrition Bulletin 2011; 32: 175-294.

20. Knudsen N, Bulow I, Jorgensen T, Laurberg P, Ovesen L, Perrild $\mathrm{H}$. Comparative study of thyroid function and types of thyroid dysfunction in two areas in Denmark with slightly different iodine status. Eur J Endocrinol 2000; 143: 485-91.

21. Laurberg P, Cerqueira C, Ovesen L, Rasmussen LB, Perrild $H$, Andersen S, Pedersen IB, Carle A. lodine intake as a determinant of thyroid disorders in populations. Best Pract Res Clin Endocrinol Metab 2010; 24: 13-27.

22. Hollowell JG, Staehling NW, Flanders WD, Hannon WH, Gunter EW, Spencer CA, Braverman LE. Serum TSH, $\mathrm{T}(4)$, and thyroid antibodies in the United States population (1988 to 1994): National Health and Nutrition Examination Survey (NHANES III). J Clin Endocrinol Metab 2002; 87: 489-99.

23. Lago-Sampedro AM, Gutiérrez-Repiso C, Valdés S, Maldonado C, Colomo N, Almaraz MC, Rubio-Martin E, Morcillo S, Esteva I, Ruiz de Adana MS et al. Changes in thyroid function with age: results from the Pizarra population-based longitudinal study. Int J Clin Pract 2015; 69(5): 577-87.

24. Bremner AP, Feddema P, Leedman PJ, Brown SJ, Beilby JP, Lim EM, Wilson SG, O'Leary PC, Walsh JP. Age-related changes in thyroid function: a longitudinal study of a community-based cohort. J Clin Endocrinol Metab 2012; 97: 554-1562.

25. Baloch Z, Carayon P, Conte-Devolx B, Demers LM, FeldtRasmussen U, Henry JF, LiVosli VA, Niccoli-Sire P, John $\mathrm{R}$, Ruf J et al. Laboratory medicine practice guidelines: laboratory support for the diagnosis and monitoring of thyroid disease. Thyroid 2003; 13(1): 57-67.

26. Netto LS. Subclinical thyroid disease: scientific review and guidelines for diagnosis and management. JAMA 2004; 291: 228-38. 
27. Gonzalez-Sagrado M, Martin-Gil FJ. Population-specific reference values for thyroid hormones on the Abbott ARCHITECT i2000 analyzer. Clin Chem Lab Med 2004; 42(5): 540-2.

28. Hollowell JG, Staehling NW, Flanders WD, Hannon WH, Gunter EW, Spencer CA, Braverman LE. Serum TSH, T (4), and thyroid antibodies in the United States population (1988 to 1994): National Health and Nutrition Examination Survey (NHANES III). J Clin Endocrinol Metab 2002; 87: 489-99.

29. Unuane D, Tournaye H, Velkeniers B, Poppe K. Endocrine disorders \& female infertility. Best Pract Res Clin Endocrinol Metab 2011; 25(6): 861-73.

30. Kahapola-Arachchige KM, Hadlow N, Wardrop R, Lim EM, Walsh JP. Age-specific TSH reference ranges have minimal impact on the diagnosis of thyroid dysfunction. Clin Endocrinol 2012; 77(5): 773-9.

31. Lincoln SR, Ke RW, Kutteh WH. Screening for hypothyroidism in infertile women. J Reprod Med 1999; 44: 455-7.

32. Poppe K, Glinoer D, Van Steirteghem A, Tournaye H, Devroey P, Schiettecatte J, Velkeniers B. Thyroid dysfunction and autoimmunity in infertile women. Thyroid 2002; 12: 997-1001.

33. Razvi S, Shakoor A, Vanderpump M, Weaver JU, Pearce $\mathrm{SH}$. The influence of age on the relationship between subclinical hypothyroidism and ischemic heart disease: a metaanalysis. J Clin Endocrinol Metab 2008; 93: 29983007.
34. Rostami S, Fathollahpour A, Abdi M, Naderi K. Alteration in prooxidant-antioxidant balance associated with selenium concentration in patients with congenital hypothyroidism. J Med Biochem 2018; 37: 355-63.

35. Waring AC, Arnold AM, Newman AB, Buzkova P, Hirsch C, Cappola AR. Longitudinal changes in thyroid function in the oldest old and survival: the cardiovascular health study all-stars study. J Clin Endocrinol Metab 2012; 97: 3944-50.

36. Van de Ven AC, Netea-Maier RT, Smit JW, Kusters R, van der Stappen JW, Pronk-Admiraal CJ, Buijs MM, Schoenmakers $\mathrm{CH}$, Koehorst SG, de Groot MJ et al. Thyrotropin versus age relation as an indicator of historical iodine intake. Thyroid 2015; 25(6): 629-34.

37. Larsen PR, Zavacki AM. Role of the iodothyronine deiodinases in the physiology and pathophysiology of thyroid hormone action. Eur Thyroid J 2013; 1(4): 232-42.

38. Thienpont LM, Van Uytfanghe K, De Grande LAC, Reynders D, Das B, Faix JD, MacKenzie F, Decallonne B, Hishinuma A, Lapauw B, et al. IFCC Committee for Standardization of Thyroid Function Tests (C-STFT). Harmonization of Serum Thyroid-Stimulating Hormone Measurements Paves the Way for the Adoption of a More Uniform Reference Interval. Clin Chem 2017; 63(7): 1248-60.

39. Thienpont LM, Van Uytfanghe K, Van Houcke S, Das B, Faix JD, MacKenzie F, Quinn FA, Rottmann M, Van den Bruel $A$ et al. A progress report of the IFCC committee for standardization of thyroid function tests. Eur Thyroid J 2014; 3(2): 109-16. 